\title{
Neurokinin-3 Receptor Antagonist
}

National Cancer Institute

\section{Source}

National Cancer Institute. Neurokinin-3 Receptor Antagonist. NCI Thesaurus. Code C142789.

Any agent that inhibits the activity of the neurokinin type 3 receptor. 